\title{
The fictional transfiguration of Jesus: Images of Jesus in literature
}

C W du Toit

Institute for Theology and Religion

University of South-Africa

\begin{abstract}
Over the years the literary world has been one of the most productive and creative sources of jesus interpretation. This article gives an overview of som aspects of developments in this filed with reference to the African and Afrikaner contexts. The way in which Jesus is fictionally transformed may reflect the influence of scholarly research, popular and innovative Jesus interpretations, existential questions, and cultural fluctuations, or simply a celebration of imagination. The relationship between theology and literature is vital to both fields. Theology is challenged by the freedom of the novel and the novel stimulated by theological findings. After dealing with some categories of fictional narratives, a few examples are discussed. The article gives attention to Jesus in postmodern novels and in postcolonial literature. An African novel is referred to and then Jesus is dealt with more extensively in Afrikaans poems. Examples are given from the work of Sheila Cussons, Breyten Breytenbach and Adam Small. The article closes with the sentiment that Jesus interpretations remain a critical and creative comment on humankind and its religion.
\end{abstract}

\section{INTRODUCTION}

In the beginning was the Word and the Word became a book which was multiplied infinitely. Other books followed, all trying to understand, reinterpret, and comment on this Word. These books not only mirrored the world of their time, they also interpreted it in order to address the hopes and fears of humankind. More books were written to secure this Word, which was controlled by the churches. This Word was sometimes studied to be rejected; it was fictionally transformed for the aesthetic and spiritual fulfilment it offered. In a sense it is impossible to retrieve the Word behind the myriad words that followed. Reaction against logocentric ideas, as well as the rejection of the ideal of a historical restoration of this archaic word rendered efforts of retrieving it

\footnotetext{
* Paper presented at the Images of Jesus Seminar, Research Institute for Theology and Religion,
} University of South Africa, September 3-4, 1997. 
worthless. The notion of the Word as a single coherent concept has been challenged adequately. But this has opened up creative and imaginative avenues for the Word to be reformulated in many different contexts and for it to establish new relations.

The New Testament itself does not portray only one, unique image of Jesus. Wessels (1986:169-170) refers to some New Testament christologies that one can identify: a Logos christology, or a Kurios christology; a prophet's, or a high priest christology; a discipleship, Servant-of-the-Lord, or Son of God christology. One can also derive a variety of christologies from the interpretations of Christ held by Palestinian Jewish Christians, Jewish Christians of the diaspora, and Hellenistic Christians. If this multiplicity of images is true of the New Testament, it is true of the evolution of these images through history, in different epochs, and in different cultures. Images of Jesus are images of meaning and understanding, depending on the world, context, genre and need to which they relate. There is a correlation between popular images of Jesus and the images of Christian life. Borg (1994:194) gives the following examples: if a Christian is persuaded that Jesus taught a subversive wisdom or a specific purity system, this will affect the way that person views the conventional wisdom or specific purity system of his/her age; if a person becomes persuaded that Jesus indicted the ruling elites of his day, it affects how domination systems are seen in the present. Any significant change in a Christian's perception of Jesus in fact affects that person's perceptions of the Christian life.

It is also impossible to really know the historical man embodying this word. The Jesus of history is often confused with the Christ of faith. The Christ of faith cannot enjoy a privileged position above the historical Jesus. For Crossan (1994:xi) an impartial account of the historical Jesus can be done only when separating it from an account of the confessional Christ. One cannot do an autobiography and still call it a biography. However, we are influenced by more than confessional factors when grappling with the historical Jesus.

Borg (1994:192-193) agrees with Kähler and Schweitzer that historical knowledge of Jesus is not essential to being a Christian. Christianity has been 'working' for centuries, before the ideas concerning the historical Jesus were developed in the quest originating a couple of centuries ago. Religious traditions can mediate the sacred independence of their historical or literal truth. The independent mediation of faith, however, concerns faith in its dimension as a personal relationship. When faith refers to the tradition and history of Christianity, this does imply a historical knowledge of Jesus. To some extent historical decisions are already shaped by ideology. What we take to be fact emerges out of our interpretative systems (Hamilton 1994:181). Nevertheless, this cannot render historical enquiry senseless. For Hamilton $(1994: 18,22)$ the Jesus of history which the nineteenth century thought it had discovered was an illusion product not of objective scholarship but of need. The theologians and historians can 
offer neither a convincing Jesus of history nor a Christ of faith. Jesus concerns more than the choice between belief or disbelief ${ }^{1}$. Hamilton seems to be more at ease with a position where freedom of belief allows the possibility of being religious without being bound by any fixed dogma or belief system. This approach is also reflected in many of the novels discussed in his book. Many people, no longer having strong religious ties, regard the figure of Jesus with an aesthetic detachment bound by few preconceptions of doctrine and denomination (Ziolkowski 1972:viii). For many, Christianity continues to be important long after it has ceased to be true (in the historic and literal sense of the word). This is reflected in many fictional transformations of Jesus in which, from a theological perspective, unexpected interactions with Jesus become possible. We recognise that the Gospels were not written to answer our questions, but we continue to relate these questions to the Gospels. For Hamilton $(1994: 8,17,20)$ the Gospels themselves are fiction. If the Gospels can be read as fiction, this means a renewed importance for the apocalyptic tradition and contemporary works of fiction about Jesus take on a new importance and interest.

Jesus is a fiction in the fictions of others. Jesus and Socrates are literary activators who left no literary works but triggered an unforeseen outcome, of which the endless stream of literature is only a part. What we have of Jesus depends on the primary image of Jesus as fiction in the fictions of others (see Kent 1989:37). The fascination Jesus holds seems to exceed strict religious and spiritual dimensions. It concerns also the literary possibilities opened up by the Jesus fiction. The Jesus fiction allows comment and critique on worldview, God concepts, church and society - something that would not be possible outside this genre.

The last two decades have seen an amazing rediscovery of Jesus as literary figure ${ }^{2}$. Some speak of a literary renaissance of Jesus, especially of the Jesus novel (see Langenhorst 1992:752). Since the 1980s, in particular, many writers have shown a renewed interest in rediscovering Jesus in his time by literary means. Since then many Jesus novels from the fifties have been reprinted. Jesus remains a figure of worldwide interest. His person and work seem to remain a source for an endless stream of novels. Authors write about him in historical novels, they present their very own account of his life and ideas, they send contemporary figures of our time back into history to give their own report of what had happened, they approach Jesus by reporting the witness of a whole range of his contemporaries, and they use legendary or mythical figures to give a portrait of him (Langenhorst 1995:85,96).

To examine the images of Jesus in non-theological literature is almost impossible since hundreds of titles in poetry, fiction and drama can be cited, each portraying a specific picture of Jesus. These images vary in motive, scope and perspective. They may celebrate fiction as a medium for a good story, display ulterior motives of importance for the author, reflect the stance of Jesus research, react on church dogma and 
tradition, or simply reflect general sentiments about Jesus. To demarcate and catalogue the literature to be studied is also difficult. Jesus fictions are not a genre different from fiction as we know it. Jesus fictions cannot be evaluated without taking account of the forces of convention and tradition that shaped them (Ziolkowski 1972:vii).

Jesus is not always dealt with explicitly in fiction. His values, words and examples are often dealt with in an indirect manner, as will later be indicated. He is, however, fictionally transfigured in narratives in which the characters and the action, irrespective of meaning or theme, are prefigured to a noticeable extent by figures and events associated with the life of Jesus as it is known from the Gospels. The modern hero whose life is prefigured by the life of Jesus may occasionally be a good or even Christlike man, an obsessed paranoid, a Nietzschean elitist, an atheistic Party functionary, or a scheming opportunist ${ }^{3}$. In his moral actions the Christ figure of modern literature often does not reflect Christ at all (Ziolkowski 1972:6, 9). Since the events set down in the Gospels prefigure immutably the action and the plot of the novel, one can expect the outcome to be inevitable. This is not necessarily so; the way each author structures his work is unique.

\section{THE RELATIONSHIP BETWEEN THEOLOGY AND LITERATURE}

Although theology and literature are interdependent disciplines there are also overlapping interests demanding interdisciplinary contact. Theology lives in and from the world of literature and this includes secular meta-texts. Literature has always been influenced by theology in many ways. Both worlds have as immediate concern the world of texts, the understanding and interpretation of texts, and the writing of texts. Developments in literary criticism, hermeneutics and exegesis concern both disciplines. But so-called secular texts may embody a depth of religious and spiritual wealth foreign to theological considerations. This already sounds the traditional demarcation between the novel and theology. Christian theology is, traditionally, to a large degree restricted in its deliberations by the Bible as text, by dogma and creeds as boundaries of thought, and by the Christian ethical norms in its application. The novel is free. The novel may pose critical and challenging questions invaluable to theology, uncomfortable to the God of dogmas and creeds. Apart from this, the religious novel allows a creative implementation of imagination. Imagination is celebrated in a century where humanity feels bereft of objective foundations of truth, ghosted by a deus absconditus and devoid of any compelling sense of real presence. In the postmodern imagination images no longer refer to some transcendental signified, whether outside the human subject as in Platonism or inside the human subject as in modern idealism. Images now refer to 
other images. There is no origin of meaning in which images can be said to present or represent. The postmodern imaginary circulates in an endless play of simulation (see Kearney 1991:7). In considering the images of Jesus as displayed in fictional transfigurations there is more at stake than simple innovative ways of retelling the Jesus story. Not only do doctrinal variations and theological alternative ideas come to the fore, but also critique on church and society, questions concerning the style of living induced by a Christian culture, and comment on the value of theological deliberations. Cultural comment is by implication comment on the influences which religion exerts on that society. In the words of Kundera (1988:5) 'The novel has accompanied man uninterruptedly and faithfully since the beginning of the Modern Era ... its raison $d$ ' etre is to discover what only the novel can discover, protecting us against - "the forgetting of being"'.

Fictional transfigurations of Jesus as found in novels, poetry and plays enable us to look at the Gospels from a new perspective. They ask questions about the historical reliability of the Gospels and the adequacy of theological interpretations and traditions which are worth considering (Langenhorst 1995:97). It would, however, be foolish to restrict their meaning only to this use. Although the theological and religious interests in the Jesus novel may focus on the way Jesus is depicted, on the extent to which Jesus research is reflected in these novels, on the religious overtones present, on the societal and ecclesiastical critique displayed, the Jesus novel remains a literary work which should be evaluated from a literary point of view. In this regard the following issues can be stressed: what are the literary techniques implemented by authors, and are they convincing; can the Jesus-figure be implemented in a literary context at all (Langenhorst 1992:752)?

The literature under investigation has been written from a Christian worldview which indirectly and even subconsciously codetermines what is said. Jesus is dealt with in the context of all the creeds, confessions and beliefs of Christianity, which means that belief in God, salvation, humankind, the future and so on forms the background of statements about Jesus.

\section{CATEGORIES OF FICTIONAL NARRATIVES}

There are no hard and fast rules when it comes to categorising novels. Although each novel is unique, certain common techniques, approaches and styles typical of the Jesus novel can be identified.

Langenhorst (1992:752) identifies four what he calls 'literary techniques' in the Jesus novel over the last few years: 
* Jesus is presented as he is here, just as in the classical historical novel.

* He is described from the perspective of some biblical character.

* His special identity is shaped through the witness of several of his contemporaries.

* He is confronted by nonhistorical figures in the context of the fictional legend.

Hamilton (1994:134) refers to motives or forms rather than categories among those writing Jesus fiction: the author may simply wish to write a bestseller; may defend an assured orthodox belief system or a heterodoxy or may simply write for literary delight and fun. Apart from the marginal character device where Jesus is described through the use of a well-known character from the Gospels (Pilate, Barrabas, Judas, Mary Magdalene, Caiaphas, and so on), Hamilton (1994:153) also distinguishes those Jesus fictions in which Jesus 'himself' returns to earth.

Ziolkowski (1972:13ff) identifies four categories of Jesus novels in which Jesus is fictionally transfigured. They are: fictional biographies, fictional transformations, the imitatio Christi novels (commitment novels), and pseudonyms of Christ. These are briefly discussed below.

\subsection{Fictional biographies}

Fictional biographies must be distinguished from fictional transfigurations since their subject is the historical Jesus, not the modern hero whose life is simply prefigured by Jesus. In these biographies Jesus takes up the images and tastes of the times. These works are designed to produce a poor man's Jesus requiring no imagination. Fictional biographies are often not regarded as works of literary distinction. They are more interesting as fiction when the figure of Jesus is not presented directly by the author, but is portrayed indirectly through the eyes of the character (Ziolkowski 1972:17). For example, one can refer to Jim Bishop's The day Christ died (1957) in which the author describes what happened in Jerusalem just as a contemporary journalist would have done in a pretence of journalistic accuracy. The author claims to be dealing only with facts and deals hour by hour with the period between Jesus' arrival in Jerusalem (18:00 on Thursday) and his deposition from the cross (16:00) the following afternoon. The work moves, however, from the very first sentence beyond objectivity into a fictional recreation of events (Ziolkowski 1972:15).

The other variant of fictional biographies is that in which authors add their own psychology or point of view. Some excellent examples are Robert Graves's King Jesus, Nikos Kazantzakis's The last temptation of Christ (1953), Pär Lagervist's Barrabas (1950) and Lloyd C Douglas's The big fisherman (1948). Langenhorst (1995:86) 
has a high esteem for fictional biographies and what they achieved in their time. He sees the fifties as the peak and also the end of this genre. In the sixties monoperspective novels with omniscient narrator figures and well-defined messages went out of fashion. Church members asked for more than a colourful reproduction of the biblical narratives that neglected the critical questions about the historicity of the events. Although so-called fictional biographies seemed to die out in the late fifties, the genre in its time contributed to a rediscovery of Jesus as a literary figure, of Jesus in his time (Langenhorst 1995:87).

\subsection{Fictional transformations}

Ziolkowski (1972:17ff) distinguishes as fictional transformation a category which he calls Jesus redivivus: stories set in modern times, in which the historical Jesus appears miraculously. The effect of this genre often depends upon the intentional anachronism and incongruity between past and present. Fictional transformations as a genre differ from fictional biography to the extent that they introduce a modern hero and not the historical Jesus himself. They differ from the imitatio Christi and the 'pseudonyms of Christ' to the extent that the action is specifically based on the life of the historical Jesus as depicted in the Gospels and not by ideas pertaining to the kerygmatic Christ (Ziolkowski 1972:21, 29).

The most famous in this category is probably Dostoevsky's The brothers Karamazov (1880). Some other works in this category are: William T Stead's If Christ came to Chicago (1894), Max Kretzer's The vision of Christ (tr of German edition 1897) and Upton Sinclair's They call me carpenter (1922).

\subsection{The imitatio Christi novels (commitment novels)}

This refers to the homonymic book of Thomas à Kempis which became paradigmatic for novels in which the hero makes up his mind to live consistently as Jesus would have lived had he been born in our world. Novels in this category do not concern the 'resurrected' historical Jesus, but modern heroes who act out their conception of Christ. The historical Jesus is only a vague background against which the Christ of faith operates in these novels. Of primary importance in this genre is the decision and commitment to live and act as the authors think Jesus did. As an example, the Bible Belt classic by M Sheldon In his steps (1896), can be mentioned. It has been translated into more than twenty languages and represents the ultimate model of inspirational fiction for fundamentalist Americans (Ziolkowski 1972:22-26). 


\subsection{Pseudonyms for Christ}

This broad category includes any novel in which the hero is felt to be somehow 'Christlike'. The plot is highly relative and depends on the author's understanding and interpretation of Christianity. This does not mean that the figure of Christ must play a redemptive role, although this is often the case. The common denominator in this category is, however, not the New Testament figure of Jesus but the archetypal figure of the redeemer. It introduces the modern hero and not the historical Jesus himself. His actions are based on the life of the historical Jesus as depicted in the Gospels and not on the Christ of faith. Examples of this genre are Dostoevsky's The idiot and Crime and punishment, Camus The stranger, Faulkner's The bear, Hemingway's The old man and the sea and Kafka's The trial (Ziolkowski 1972:26-29).

\section{A DISCUSSION OF A FEW NOVELS}

\subsection{Dostoevsky's The idiot (1867-1868) (see Hamilton 1994:73ff)}

Dostoevsky's Jesus is mediated solely through a fictional character. In his portrait of prince Myshkin Dostoevsky tried to come to terms with his own understanding of Jesus. Myshkin was a Jesus answering Dostoevsky's deepest needs. In the early half of the novel the prince is both evil and good and only gradually does the character evolve towards a more unambiguous one of purity and virtue. The awkward fact is that the prince does not cease being evil as he becomes more and more like Jesus. There are three key scenes. The first story tells of his friendship with Marie. Myshkin sees himself as an innocent person, at home with children. Myshkin describes his friendship with a group of children. In becoming a child himself he can become Jesus.

The second scene is Ippolyt's 'confessions'. Ippolyt sees the prince as a pious and gentle idiot in an evil world. The third scene concerns the description of a painting of the 'Dead Christ'5. If this good man was brutally murdered long ago, how can it surprise us that innocence will always destroy and be destroyed? This painting casts a shadow over the prince's powerlessness and dangerous innocence. Ippolyt comments on the world depicted in Holbein's painting in his confession. In the painting, where Christ is shown as having just been removed from the cross, God and the devil are simultaneously in control. The Myshkin Jesus made a profound impression wherever he went, but left destructive traces. The Jesus portrayed in The Idiot is decent and destructive in his innocence. This comes to the fore in the fact that Myshkin has pity and compassion, but no ability to love. He is a Christian but does not believe. He has religious experiences but these are related to his epilepsy (Hamilton 1994:78). Dostoevsky persuades the reader to see Myshkin as Jesus by giving him virtues associ- 
ated with the Christian tradition: He has no enemies and cannot imagine being an enemy to anyone. He attacks Roman Catholicism (purging rite) and predicts the resurrection of a new Russian Jesus who will transform and empower the people.

\subsection{The Brook Kerith by George Moore (see Hamilton 1994:197-202)}

This novel makes use of the marginal character device where Jesus is reinterpreted through the eyes of a marginal biblical figure. This technique dominates the first part of the book. The second half implements what can be called the 'what if Jesus didn't really die?' genre. Moore's novel succeeds in combining Jesus interpretations with experiments in fiction - a fect rarely achieved. The marginal character is Joseph of Arimathea who becomes an ardent admirer of Jesus the Essene. Moore records in this novel some gospel miracles of Jesus and expands on a few in an attempt to improve on them. In the story Jesus is portrayed at the end of his life as a bitter apocalypticist, only marginally sane, uncontrollably angry and condemned to death. Joseph procures Jesus' body after the crucifixion, discovers that he is not dead, helps him to recover and moves him to the nearby Essene monastery, which in the meantime has shifted closer to Jerusalem, to the Brook Kerith. Shortly hereafter, Joseph is killed and Jesus leaves the monastery for the fields where he becomes a shepherd for the next four years. He reflects on his past and comes to terms with the trauma of his crucifixion. He comes to deeply regret his messianic pretensions, his apocalyptic, world-hating pessimism, his language of destruction and hate. The final stage in the evolution of Moore's Jesus is a turning away from everything in the New Testament message, even from God himself. Moore's Jesus becomes a first-century death-of-God theologian. In this, Jesus finds peace, some twenty years after his crucifixion. Jesus then meets Paul, but does not initially reveal himself. Jesus hears for the first time about Christianity from Paul. When Jesus tells Paul his story Paul flees in horror, followed by Jesus, who tells him his gospel is based on a lie. Paul considers this a lie and Jesus as mad. Jesus then says '... All things are God, Paul: thou art God and I am God, but if I were to say thou art man and I am God, I should be the madman that thou believest me to be' (Moore: 385-386, quoted by Hamilton 1994:202). Jesus considers the possibility of travelling to Jerusalem to visit the Jewish leaders and identify himself. He decides, however, to be tolerant: why distress so many unnecessarily? Moore's Jesus has truly risen - risen to be a profound human with compassion and love for the world.

\subsection{Barabbas by Pär Lagervist (Hamilton 1994:202-204)}

In this novel Barabbas is - in a surprising way - the marginal figure through which the Jesus story is approached. Barabbas is a spiritual seeker and instrumental in Jesus' burial and renewal. Lagervist's novel reflects Swedish Lutheranism, with its emphasis 
on the Anselmian substitutionary doctrine of atonement. The novel begins with Barabbas' release from prison. He is somewhat bewildered but not changed by seeing the dying Jesus on the cross. For Barabbas the Messiah could not possibly have died like that. He later sees the empty tomb, hears of the resurrection, meets the disciples whom he finds to be unfriendly and stupid, and is still not changed. For the next twenty years he works as a slave in the Roman copper mines. Through the mediation of a Christian friend, Sahak, they are granted an interview with the Roman governor. Sahak, who refuses to give allegiance to Rome, is crucified. Barabbas denies the Christian God, is spared and goes to Rome. For the second time he is saved by the death of another. Barabbas emerges as a character during the fire of AD 63-64 in Rome. He becomes a committed believer and thinks he is helping Jesus. He sets some buildings on fire himself. Rome is doomed and he believes the Saviour is about to return. He tells the Romans that Christians are responsible for the fire. He is arrested with some Christians falsely accused of arson. He is crucified, along with others.

\subsection{Nikos Kazantzakis's The last temptation 6 (Hamilton 1994:204-209; Ziolkowski 1972:124-141)}

Ziolkowski 'classifies' this novel under the category The Christomaniacs. This is to indicate that the parallels with the Jesus story are psychologically motivated. Fantasy gradually displaces reality in the minds of the heroes, who actively begin to seek out their own passion in imitation of the Jesus with whom they have come to identify themselves (Ziolkowski 1972:140). The last temptation is an internal and existential drama.

In this novel Jesus is described from the perspective of his struggle against his sexuality and from the marginal figures of Mary Magdalene and Judas. Jesus struggles throughout his life against the flesh and conquers it only when he fully denies it. The novel opens with Jesus as a young virgin, a nerd, and practitioner of masochistic selflaceration, tormented by God. He is by profession a maker of crosses used by the Romans to crucify Zealots. Kazantzakis's Jesus is fully divine and human from the beginning of the novel. The author seems to have little interest in Jesus' relation to his own Jewish culture and land. Jesus is hardly Jewish.

In the story, as in the gospel narratives, miracles abound, setting the scene for what is to follow. Judas believes that Roman power must be overturned and gives the high priest the information for Jesus' arrest. The struggle in Gethsemane is unconvincing and Jesus walks in a docile manner, but triumphantly, to his death. He never doubts the necessity of his death. The last temptation comes in the form of a flashback dream on the cross. He reflects that he should perhaps have gone with bourgeois 
respectability. In this dream Mary Magdalene finally gets Jesus into bed. Then Paul of Tarsus kills her, and Jesus takes both the Bethany sisters as wives. But Jesus rejects this. The flashback on the cross ends and he offers his suffering messiahship to God.

There are fascinating parallels in this novel with the personal life of Kazantzakis (1882-1957). Throughout his life he was obsessed with the figure of Jesus. He was a man of extremes, spent six months in a monk's cell on Mount Athos in Macedonia without the desired effect and converted successively to nationalism, communism, and nihilism which tempered his view of Jesus. An incident with a woman caused him to suffer from the so-called 'saint's disease' - 'a neo-ascetic psychosomatic disease stemming from feelings of guilt associated with the temptation of the woman' (Ziolkowski 1972:124-127). It reminds one of Kundera's (1988:91) statement that the form of a novel, its 'mathematical structure' is not a calculated thing; it is an unconscious drive, an obsession.

\subsection{William Faulkner: A Fable (1954)}

The Jesus fictions that use the idea of Jesus who returns to earth are well placed to comment on the development of Christianity, on Christian dogma, and on present society. Faulkner's Fable and Upton Sinclair's They call me carpenter are perhaps the best known examples.

In Faulkner's A fable (see Hamilton 1994:253-260), Jesus' Second Coming is essentially a repetition of the original agony. The Christ figure is again scorned, betrayed and deserted. He knows he is doomed and offers neither hope nor a belief in the idea of hope. The novel gives a very pessimistic portrait of human nature, and attacks an evil (Calvinist) God. Three thousand soldiers come under the mysterious influence of a corporal and refuse to attack the Germans - a manoeuvre which was in any event intended for failure. The Germans refuse to counter-attack and ultimately the British also lay down their arms and the war stops. The generals are horrified at the prospect of peace and unemployment. The allies and enemies negotiate the resumption and necessity of the war, and why it failed in its purpose. The corporal (Jesus) and his twelve associates (disciples) are arrested. The corporal is killed and eventually ends up buried in the tomb of the Unknown Soldier. Faulkner tums the leader of the mutiny into Jesus in two ways. He sets him in the midst of the events of the Passion week, and creates obvious parallels with Jesus. He has a twelve-man squad, is engaged to a girl called Magda, a kind-hearted prostitute. He is captured on Wednesday, distributes a meal to his friends on Thursday and is killed on Friday - shot while tied to a post between two robbers. Hamilton (1994:256) regards this as a weak novel with a power- 
ful message. The distinctive scene in $A$ fable is the one between the old general (who turns out to be the corporal's (F)father) and the corporal the night before the execution. The general is both devil and God (the Father).

As devil he tempts his son to escape. He offers liberty, life, earth and arranges an escape trip to South America. The corporal refuses to desert his friends. The dialogue is also an intra-Trinitarian discourse between Father and pre-existent son on the nature of the incarnate life to come. The general's final criticism is that his son believes that humankind can be saved and that only his (the son's) redemptive death can save humankind. The father continues that humankind is too evil to be saved. He tells his son that "it is not a "saviour" like you that will save man or give him his eternity, it is man's own infinite capacity for evil'. In other words it is not some redeemer or god that can save humankind. Humankind can outlast wars and take hold of immortality exactly by virtue of this radical evil. As a fool, humankind is immortal. Humankind will last because wars will last and people will always find a reason for going to war if they really wish to. The corporal Jesus seems powerless before the brutal reality of humankind's inclination towards violence and evil.

Faulkner's novel also fits what Ziolkowski calls the "fifth gospel novels'7, which refers to a generation of authors born in the late twenties, early thirties ${ }^{8}$. Authors like Lars Görling, Günter Grass, John Barth and Gore Vidal are discussed under this category by Ziolkowski. Gone here is the previous veneration for the figure of Jesus. In these novels the hero takes on the colour of the environment and displays parallel similarities, emphasising points of importance for the current environment. Ziolkowski (1972:226) ascribes this to the inevitable concomitant of a theological movement that has proclaimed the death of God. If God is dead, it follows that Jesus might be reduced proportionally in his role.

\subsection{A J Langguth's comic novel Jesus Christ (1968) (Hamilton 1994:265ff)}

This example pushes the point that all religions are determined by the form of society in which they originate (see Hamilton 1994:39). This novel is a narrative experiment. In the novel Jesus keeps coming back, again and again, sometimes to the first century, sometimes to the twentieth or to an unspecified time. Apparently he comes to improve on or criticise, or deny, or laugh at his 'first' coming. An attitude of half-belief is expressed in a dialogue between an imprisoned Jesus and a guard who accuses Jesus about the guilt he has managed to breed in any man or woman or child fool enough to give him a hearing. This inculcated guilt and sense of failure have been raised to a level of perfection that has never been matched. He accuses Jesus of striking at the best of persons - if they live a blameless life, they are condemned for their thoughts. 
If they manage to live as they have been formed to live naturally, they are threatened with eternal fire. The guard continues, confessing at the same time that he is speaking to a Jesus who cannot escape (Hamilton 1994:266-267).

\subsection{Steinbeck's Grapes of wrath (1939)}

This work belongs to the category Ziolkowski reserves for those novels that portray a Jesus who gets politically involved, taking up the cause of the social underdog - the comrade Jesus. The hero is spokesperson for a new humanity, one who holds the narrative together largely through the force of his own personality. These novels refer to symbolic qualities or circumstances rather than to the person of Jesus. The allegorical dimension of these works is sophisticated. The transfiguration takes place insofar as the hero ironically realises the parallels into which he has been thrust by history (Ziolkowski 1972:223-225). The authors of novels of this genre have the highest regard for Jesus, whether they consider him to be historically real or whether he is considered to be mythical projection.

The well-known example in this category, Steinbeck's Grapes of wrath, is an American novel of social protest ${ }^{9}$. Steinbeck reacts against the greed of the big landowners who exploit the sharecroppers. He is outraged at the hunger and poverty that exists among migrants in the face of so much prosperity in California. His answer to these problems, in contrast to the moral reform proposed in the Christian socialist novels, is a political one. His transfigured hero, Jim Casey, gives up the ministry to become a union organiser, and Tom Joad decides at the end of the novel to devote his life to the cause of labour (Ziolkowski 1972:182-193).

\subsection{A Jesus play: An inspector calls (1950) by J B Priestley (Hamilton 1994:211ff).}

There are a number of Jesus plays that deal with a group in some kind of distress, and the coming of a visitor, a stranger, with a successful diagnosis and cure. The stranger often acts like Jesus, comes to think of himself as Jesus or is a Jesus surrogate.

The setting for An inspector calls is a dining-room in the English Midlands where the Birlings are celebrating their daughter Sheila's engagement. Also present are Gerald (the fiancé) and Eric (their younger son). Inspector Goole arrives and asks the family questions about a young woman who had committed suicide that night by taking poison. The inspector serves as a kind of Jesus, returned as judge. Mr Birling identifies the woman from the photograph which the inspector shows them as Eya 
Smith, a young woman he had fired several years before because of her activity as a strike-leader. Thereafter Eva had taken up a position in a dress shop, where Sheila had been instrumental in getting her fired because she was irrationally jealous of Eva's good looks. It also appears that Eva (now known as Daisy) had been Gerald's mistress during the previous year. He had broken off their relationship after some time, and Eva-Daisy had applied for aid from a charity committee chaired by Mrs Birling, who had subsequently refused any assistance. It is also revealed that Eva had become pregnant by Eric, the young Birling son, who helped her with money he had stolen from the office. All five were guilty. The Last Judgement has taken place and all are found guilty. But the play is not over. It soon becomes known that there is no inspector named Goole at the local police station. And no suicide corpse has recently been received by the infirmary. The elder Birlings conclude that since they will, after all, not be found out, they have really done nothing wrong, while the younger Birlings do not feel exonerated at all. The two responses of complacent shamelessness and serious guilt coexist until the final moment of the play when a phone call is received from the local police. A young woman has just died on her way to the infirmary after swallowing poison, and an inspector is on the way to the Birlings to interrogate them.

\section{JESUS IN POSTMODERN NOVELS}

Biblical narratives usually reflect a deeper master narrative, for example the Christian message or the Word of God. In contrast to this the postmodern biblical narrative both uses and abuses, installs and then subverts, the very concepts it challenges. Novelists have realised that as soon as you create an imaginary being, a character, you are automatically confronted by the question: what is the self? How can the self be grasped (Kundera 1988:23ff)? The Jewish proverb 'man thinks, God laughs' refers to the fact that the more a person thinks, the more one realises that one's thoughts differ from those of others. Finally, one never is what one thinks one is. Never having heard God's laughter, one may easily think that the truth is obvious and that all persons think the same (Kundera 1988:158-159). This position is superbly demonstrated in Eco's postmodern religious novel The name of the rose (1983) (see also Raschke 1992:93ff; Breech 1989:57ff). In this novel the laughter becomes a metaphor for the relativity of truth (symbolised in the comedy of Aristotle). 'That laughter is proper to man is a sign of our limitation, sinners that we are' (Eco 1983:474). Absolute truth, being the possession of the church and symbolised by the Book, books or the library, is fixed and certain. In the words of Jorge (Eco 1983:399), 'Preservation, I say, and not search, because it (truth) is a property of knowledge, as a human thing, that has been defined and completed over the course of centuries, from the preaching of the prophets to the 
interpretation of the fathers of the church. There is no progress, no revolution of age, in the history of knowledge - there is at most a continuous and sublime continuation.' From a postmodern perspective not only the notions of truth and relativity came to be questioned, but also their function in a narrative. Ricoeur has already indicated that a historical text does not refer unilaterally to reality. The historical text has the same narrative structure as fiction. The reality of any historical text is predominantly the text itself and not the extra-textual 'controllable' reality (Du Toit 1987:162). The same argument is valid for fiction. The narrative creates its own world and needs not correspond to extra-textual reality to be meaningful and 'true'. It seems that the idea of meaning is determinative to an understanding of the pleasure the text gives.

We need an ending to all stories, in the sense that a series of events is judged to be meaningful because of the outcome of those events. Human beings, according to Breech (1989:35), require a sequence of events in a story to give a kind of finality that enables us to judge who wins and who loses, who is rewarded and who punished, who succeeds and who fails. Closure, in this sense, is a useful fiction. But is this true to life? Events, as we know, are not nicely structured in binary opposites. In 'real' life there are not necessarily nice plots or endings that allow us to construe the meaning of events. Derrida (see Breech 1989:36-37) argues that we constitute ourselves in narratives because we desire to give an account of ourselves to others (as well as to ourselves) because of an impulse to judge and control. The gift of humans to notice 'resemblance (mimetic faculty) is nothing other than a rudiment of the powerful compulsion in former times to become and behave like something else' (Andersson 1993: 176). From this perspective, life stories are fundamentally a means of psychosociological control of ourselves and others. The question is thus whether we can narrate without moralising. In line with this, Kundera (1988:7) says that humankind desires a world where good and evil can be clearly distinguished, for we have an innate and irrepressible desire to judge before we understand. Religions and ideologies are founded upon this desire. Cervantes was the first to break through the barrier of a single absolute truth and to construct a world of contradictory truths (Kundera 1988:6). In 1992 the American, Gore Vidal, published Live from Golgotha, a satirical comedy described by Langenhorst $(1995: 87)$ as the first postmodern and futuristic novel about Jesus. In this futuristic novel it is possible to travel into the future or the past and to change historical events (a recipe popular nowadays in television series and computer games for kids). In the novel a computer-hacker succeeds in destroying all the tapes recording the life and message of Jesus, except for a 'gospel according to Timothy', St Paul's disciple. This 'gospel' alone ensures that future generations will know about the life and teachings of Jesus. Timothy, in his old age, is trying to record his memoirs 
when he is confronted by visitors from the future who want to influence future events by interfering with these memoirs. The visitors emphasise the importance of his writings for the future and Timothy becomes more and more unsure of what really happened: was it Judas who was crucified, and not Jesus? Was it Paul who invented the 'Good News', very much against the teachings of Jesus? Finally a television crew enters the stage, ready to record the resurrection 'live from Golgotha' for the world in the last years of the twentieth century to witness, live, but this is interpreted through Japanese eyes as 'Jesus who returns to his ancestress, the Goddess of the Sun' - and the new logo of Christianity becomes 'the cross. within the circle of the sun' (Langenhorst 1995:88).

Kent (1989:37-50) has indicated how the Protestant 'lives of Jesus' written in the nineteenth century may be thought of as fictional accounts of the New Testament Jesus equivalent to the Catholic accounts of the virgin Mary. Both sets of accounts are fictions wanting to be read as history. The masculine mask of the adult Jesus has failed to hold the attention of Western culture and the feminine mask of the transcendent has seemed to attract more attention; Mary has become one of the masks of Jesus. However, a radically feminist principle has not emerged. That has to wait for a few centuries.

Michèle Roberts ventures a radical feminist re-reading of the Bible story. In her novel The wild girl (1984) she presents a new form of Christianity that embraces both female and male and acknowledges women's spirituality (Langenhorst 1995:92).

\section{JESUS IN POSTCOLONIAL LITERATURE: AN AFRICAN EXAMPLE}

Postcolonial literature, like postmodern literature and poststructuralist criticism, rests upon dismantling and questioning the concept of hierarchy and challenging the masternarratives of history. The so-called moral responsibility to transform native economies, societies and cultures - called the white man's burden by Kipling - can also be interpreted as the white man's hunger for gold, God and glory (Gallagher 1994:20-21).

Postcolonial literature has given rise to many new forms and genres of literature, subverting previously valid generic conventions to create new forms. Theologians throughout the world, but especially in Third World countries, who wanted to speak more relevantly to their age and generation, started to free themselves from traditional dogmatic and systematic theology and focused on life issues (Gallagher 1994:25).

Postcolonial novels refer to those written since the Second World War by authors who are neither European nor American, and who replace the Euro-American Jesus figures with localised Jesus figures ${ }^{10}$. The localised and indigenised Jesus becomes a postcolonial character who protests against injustice. Many postcolonial authors 
responded to the religion brought by the missionaries by countering and mimicking the Eurocentric Christian story. Jesus is replaced by indigenous characters who are interpreted in terms of the very religions and cultures that Europeans sought to replace (Cary 1994:171, 182). Ngũgĩ wa Thiong'o is a Kenyan writer whose work $A$ grain of wheat reflects the struggle of Kenyan indigenous religion against a Christianity that is viewed paradoxically as both antithetical and helpful. Ngũgĩ attended a mission school where he eventually accused the school of preaching love while serving the cause of a colonialism based on racial and cultural inequality. Christianity is abandoned by him, as being the agent of colonial and neo-colonial control by the West.

Ngũgi's approach attempts to combine Christian symbols with Gikuyu cultural and political tradition. In $A$ grain of wheat the Mau Mau leader Kihika is the African version of 'Comrade Jesus'. Kihika, a student at a mission school, begins to see parallels between himself and the biblical deliverers he learns about, and aspires to free his people as Moses did. He tells his friends that Gandhi succeeded because he made his people give up their fathers and mothers and serve their one Mother - India. In their case Kenya is mother. The political situation calls for new Christs, because the death of the Christ of Christianity has not changed anything. When Kihika kills a British officer, he compares his assassination with the vengeance of God on the Egyptians. As the Kenyan Christ he is betrayed to the colonial authorities and hanged from a tree, 'crucified' (Cary 1994:176-177). Mugo, Kihika's betrayer, ironically sees himself from the same biblical perspective. Because of the consuming jealousy of Kihika, Mugo betrays him and is seen incorrectly as a hero by the community. which is haunted by Judas-like feelings of guilt. Mugo is put to death after confessing his guilt at a public commemoration of Kihika's death. Kihika had put his life into Mugo's hands, who sold it to the white man. Mugo identified simultaneously with Jesus and Judas (Cary 1994:178).

\section{JESUS IN AFRIKAANS POEMS}

Traditionally white, Calvinistic-orientated, Afrikaners have been regarded as very religious. This religious aptitude comes to the fore especially in Afrikaans poems. Many Afrikaans poets have shown a special interest in Christ and their work has exerted a strong influence on Arikaner communities (Van der Wart 1988:460ff). The absence of social critique, especially apartheid-critique is auspicious (the exception being coloured poets like Adam Small and a few white poets like Breyten Breytenbach and $\mathbf{M}$ M Walters). The person of Christ received most attention before the 1960s. The small, interdependent and exclusive Afrikaner communities, dominated by the Afrikaans churches, made it almost impossible to produce literary works opposed to Afrikaner sentiments. 
Changes after the nineteen-sixties affected only the style and structure - not what was being said, only how it was said. Theological development concerning the historicalcritical method and Jesus research was not followed or articulated in seminaries or churches and was restricted to a few individual scholars who had to keep their ideas to themselves. One can therefore expect Afrikaans poems about Jesus to be restricted to the personal, pious, mystical and spiritual dimensions (see Van der Wart 1988:469ff, who endorses this). Poets who maintained Christ as God and Messiah (Spies, De Villiers, Cussons) are highly esteemed, while the few who dared to stress the human side of Christ are evaluated negatively by Van der Wart, who deems them secular, disillusioned and deranged non-believers! By implication, only those poets and writers who conform to the Reformed tradition, and hold to the literal readings of Scripture, can produce acceptable work. This attitude must be understood against the background of the ideology of Christian education and philosophy, still well established in South Africa (Van der Wart 1988:471-472, 476).

\subsection{Sheila Cussons}

In several poems the poet's personal circumstances are related to the person and history of Jesus. Sheila Cussons is a good example. Her experience of being badly scalded is related to Christ in the poem Christ of the burnt men (1978) ${ }^{11}$. The title of the poem is borrowed from Thomas Merton's The sign of Jonas (1953) where the idea is expressed that whoever experiences God experiences an intense fire burning and purging him/her. The poem combines the ideas of suffering and joy, in Christ and in humans. The suffering of the poet is linked to that of Christ. Christ changes pain to the benefit of humans. The poet's wounds are seen as those of Christ crucified. The poet's wounds are a crucifixion (Van der Wart 1988:94-121).

In her poem Die vlieë ('The flies') ${ }^{12}$, Cussons sees the crucifixion through the eyes of flies. The unclean flies know about the purity of Jesus. They are attracted to this. 'sweet' and earthly Jesus. The radical nature of the incarnation is emphasised through the friendship between Levi and Jesus, and Jesus' implied ignorance of the flies around his mug. The flies, present in his life and at the cross, recognise his Godhead and asked, like the fellow-crucified, to be remembered in his exaltation (see Van der Wart 1988:441-450).

\subsection{Breyten Breytenbach}

Breytenbach, well known for his stance against apartheid, his acceptance of Zen Buddhism, and his provocative literary work is perhaps one of South Africa's most 
prolific writers. Social comment is typical of his work. Some of his poems deal with the Christ figure. He personalises and concretises abstract biblical concepts, applying them to his own historical context. His ideas are not only contrary to Afrikaner morality, but have even been experienced as offensive. For example, Holy Communion is seen as erotic communion, God as powerless, man as his own saviour (see Zen Buddhism), and Jesus as myth (see Van der Wart 1988:277ff).

In his poem Ikoon ('Icon') Christ is depicted as pinned against the cross ('teen die kruis') in the way a pin-up of Marilyn Monroe is attached to a wall. The icon that Breytenbach describes is not a conventional one, evoking veneration or depicting 'prayer in wood'. In this icon-poem Christ is not central as in the case of icons; his humanity and suffering are depicted, rather than his exaltation and power (as with icons) and the background and foreground are filled with nature, the absurd and surrealistic, which is once again quite unconventional for an icon seen as depicting the mysterious supernatural world (Slabbert 1981:52; Gilfillan 1983:25). Breytenbach's icon is, however, an artefact and one must look behind the flat, oil-painted surface into the three-dimensional depth of meaning to see the glowing, incarnated Jesus. The incarnation is banal, incomplete, suspended, the spilled blood suspended in air like stemless blossoms - man remains unredeemed (Gilfillan 1983:26-27).

The icon 'preserves' the crucifixion-event in Jesus' blood, as canned fruit is preserved in its syrup. The icon fixates and suspends the cross-event and makes it anachronistic - like a cuckoo-clock in a spaceship. This 'well-preserved' Jesus has not the slightest chance to decompose, as a sparrow impaled by a fiscal shrike would have. He is 'nailed' in paint and cannot decompose. Death cannot complete this life — all remains suspended (Gilfillan 1983:29).

The poem splits this comment on the icon with some crude images of an unsaved world, unaffected by the Jesus-event. 'People are spilling blood in spite of the spilled blood of Christ, without hope of change. Jesus remains as aloof and unreal as a Marilyn Monroe pinup. The names of both Jesus and Marilyn Monroe are written entirely in lower case letters to indicate their limited humanity. The chances of Jesus saving all are as good as those of Marilyn Monroe satisfying all men.

There is another possible dimension to this poem. The icon-poem is a metaphor for the incarcerate work of art that remains suspended (as artefact) until it comes to life again in the moment of appropriation. The work of art (art object) comes to life again when it is integrated into present existential and aesthetic concerns as a dialogue partner (art subject) (Gilfillan 1983:27). 


\subsection{Adam Small}

The work of Small displays the struggle, suffering and political aspirations of the coloured community under apartheid. His Jesus poems must be read in the light of his sociopolitical involvement. In the poem Lydensweg ${ }^{15}$ ('Via Dolorosa') he directs a satirical accusation to God. God need not care about the poet, who is his own Christ. If he (the poet) should ever be assaulted by a gang, he will die on his own cross and so be equal to God.

In the work Vyfde evangelie (1961) ('Fifth Gospel') the Jesus story is transposed to the present-day coloured community. Jesus is born a coloured man, and is prosecuted and killed under the white apartheid government. The coloured Christ is seen from different perspectives: that of an underdeveloped person, an academic coloured person, from an ANC and PAC political perspective, from the perspective of an underdeveloped as well as an intellectual white person, and from that of a leader. The Afrikaner people regarded themselves, like the Jews did, as God's chosen people. They would crucify a Christ who dared to preach impartiality between all people (Van der Wart 1988:300-301).

\section{FUTURE IMAGES OF JESUS}

The significant role the Jesus-figure plays in literature reflects some of the deepest thoughts on God and being in Western culture. This sufficiently motivates the continued importance of literary works for church and theology. The Jesus images in literature are manifold: some reflect Jesus as historical person in the historical setting of his times; in others he simply steps into modern life as if he were one of us getting involved in sociopolitical affairs, commenting on our lifestyle, expressing our problems with God, suffering, justice and evil. In others Jesus is ahead of us as the futuristic Jesus. Many images are brought to us through marginal figures trying to give us a new perspective on Jesus, and in other novels the image of Jesus is recognised in the words and customs of the characters. Most works, however, want to stress not Jesus as such, but humankind with its ideas and suffering.

The figure of Jesus remains and will remain a source of inspiration in the world of literature. How he will be depicted is unpredictable. It may be as the existential translator of life, as social reformer, political activist, spiritual leader, moralist, inter-faith mediator, cultural leader or cosmic guide. Images of Jesus created outside church dogma and independent of theological interpretation must be welcomed. They ensure a critical and creative view of humankind and its religion. Perhaps Dickenson's Tender pioneer (see Oberhaus 1987:345) says it all: 
How brittle are the Piers

On which our faith doth tread -

No Bridge below doth totter so -

Yet none hath such a Crowd.

\section{It is as old as God - \\ Indeed - 'twas built by him - \\ He sent his Son to test the Plank, \\ And he pronounced it firm.}

* This article was published in Du Toit, C W (ed), Images of Jesus, 64-97. Pretoria: University of South Africa. HTS is granted permission to reprint this article.

\section{Endnotes}

1 It is interesting to note that non-Christians and non-religius persons can write excellent Jesus novels, as Schalom Ach's The Nazarene (1939) and Max Brod's Der Meister (1952) prove. According to Langenhorst (1995:96) they do so in order to present an ethical message to humankind in times of threateningly possible human-made apocalypse. This need not, however, be the only motivation. The fascination of the Jesus figure simply offers different options to many.

2 An international bibliography of Jesus novels has been prepared by Birney (1989).

3 In the words of Kuschel (1986:209), 'Deshalb kann der Nazarener immer wieder zur manchmal offenen, manchmal geheimen Bezugsfigur menschlicher Selbsterhellung in Literatur werden. Ein Man, an dem stellvertretend Grundkonflikte gespiegelt werden, unverzichtbar auf eine Weise wie andere grosse literarische Leitfiguren, archetipischen Grund-Gestalten: Hamlet und Faust, Ödipus und Antigone, Ulysses und Hiob, Abasver und Kassandra.'

4 Because of the limited range and restricted nature of this contribution it is impossible to discuss any novel in depth. Reference will be made predominantly to the seminal works of Ziolkowski (1972) and Hamilton (1994).

5 Dostoevsky actually saw the painting 'Dead Christ' by Hans Holbein the Younger in 1867 in Basel when he was working on the novel (Hamilton 1994:76).

6 His other Jesus novel is The Greek passion, written between 1948 and 1951 .

7 The term 'fifth gospel novels' refes to a neutral point of view, outside the framework of any ethical system conventionally associated with the four Gospels of the New Testament. These works can be seen as a parody of the Gospels. 
8 Kazantzakis and Faulkner were born before the turn of the century and their works were carryovers of the older psychiatric and mythical views on Jesus.

9 Other novels in this genre are Ignazio Silone's Bread and wine (1936), Arthur Koestler's Darkness at noon (1940), Thomas Mann's The magic mountain (1934), Ernest Hemingway's For whom the bell tolls (1940), and Graham Green's The power and the glory (1940) (see Ziolkowski 1972:191-223).

10 Wessels (1986:94-115) distinguished the following African christological titles for the Jesus figure: Christ as Victor, Chief, Ancestor and Healer. See also the work of Schreiter (1991).

11 'Christ of the burnt men' (original title in English)

Jy sal my ook al hoe meer wen, glimlaggende skerts-oog blink-oog Christus wat my vervaarde jare op jou afstand gadegeslaan het: jy het jou hande nie tóé uitgesteek toe ek jou sengende wonde aan my lyf ontvang het nie maar fel jou kruis geteken oor my, in hand en voet en romp en hoof, en deur die beswyming onder druppend bloedplasma- en soutwatersakke kom skyn voor my met net die trekking van 'n glimlag van uiterste pyn om die mondhoeke, jou oë blink van ' $n$ verskriklike akkoord.

En ek begryp jy het my geteken vir die avontuur van jó́, ek wat vuur bemin en altyd waaghalsig was - $O$ wat is aan die brand in brein en hart wat brandend brand as die vlam aan die lyf en wat gaan gloei in klip en sand onder my eenvoetig-springende begrip agter jou ságsinnigheid aan?: Nee, iets heerlikers: as jy uiteindelik omdraai met oë wit en stip en ver en skouers gemantel met ' $n$ verwoede en stormende sonde: $\mathrm{o}$ my kosmiese Christus: drie-en-dertig jaar verdoesel in die klein en donker vlees wat jy in een nag oopgevlek het om jố vir my te bevry opdat ek jou raaksien, raak weet, raak het, en nog wag jy dat ek moet sê; heeluit moet sê, gryp my hande dan, amper sonder vingers vir jou: kundige timmerman.

12 Die vlieë

Die vlieë vryf hul handjies joods

kletserig in hul skik tussen die pasga-reste van my wyn en brood 
O vlieë van Galilea

op die oë van blindes, melaatses,

en op sy helende hande

en tussen die klewerige dorings:

As jy die jode se koning is

kom dan áf van jou kruis!

Maar iets gons in sy Agonie;

hou moed: soet Here, hou moed:

Vandat U saam met Levi gedrink het

waar ons om die beker gedans het

weet óns U was God en Seun van God

en dit gaan bar wees in Galilea

sonder u heerlik Huid -

Vaarwel, soet Jesus, onthou ons

as $\mathrm{U}$ aan die Regterhand sit

waaruit ons toe die wêreld begin het

óok, nietig en als, gevlie hét -

Die vlieë was hul handjies joods

volgens voorskrif van Moses

wat Hy die Haastige met slegs drie jaar

om 'n wêreld te reinig, geïgnoreer het.

13 For an excellent overview and discussion of Breytenbach as public figure see Galloway (1990).

14 lkoon

dieper agter die donker lae van velgeworde olie

plat gesmeer teen 'n houtpaneel

gloei ' $n$ ingelegde wêreld

bewaar in sy bloed soos perskes in stroop

en omdat alle volbringing gesuspendeer is

is die aksie puur en rou afgeskil

tot sinlose stellings (koekoekklokke in 'n ruimteskip)

in die voorgrond byt mense mekaar se strotte uit

die boë bloed hang verstyf in die leegte

blomknoppe sonder stingels

die pyn onder tande sal eentonig bly priem;

'n soldaat staar met peulende oë na 'n soplepel 
voor sy neus; 'n wolk buig sy skouers in versteende afwagting; ' $n$ mier beur teen die verswikking van kuite;

bo dit alles pryk 'n spykerige jesus teen 'n kruis sonder 'n gejanfiskaalde mossie se hoop op ontbinding, met 'n gryns tussen baardhare;

dieper agter vir ewig net buite bereik (soos marylin monroe)

rys 'n leë koel graf

(Coetzee 1995:26)

15 Lydensweg

so moenie worry nie Here

ek is opgafix

ek is my eie Here

en dan's ons twee kiets

prik 'n anner gêng se manne

my eendag vol snye

gaat ek sterwe aan my eie

krys vi'myne

(Van der Wart 1988:297)

\section{Works Consulted}

Andersson, D T 1993. The end of story?, in Jasper D (ed), Postmodernism, literature and the future of theology, 164-179. London: St Martin's.

Birney, A L 1989. The literary lives of Jesus: An international bibliography of poetry, drama, fiction and criticism. New York: Garland.

Breech, J 1989. Jesus and postmodernism. Minneapolis: Fortress.

Borg, M 1994. Jesus in contemporary scholarship. Valley Forge, Pennsylvania: Trinity Press International.

Cary, N R 1994. Postcolonial literature and the story of Christ, in Gallagher, S \& Van Zanten (eds), Postcolonial literature and the biblical call for justice, 169-182. Mississippi: University Press of Mississippi.

Coetzee, A 1995. Die hand vol vere. Cape Town: Human \& Rousseau.

Crossan, J D 1994. Jesus: A revolutionary biography. San Francisco: Harper.

Du Toit, C W 1987. Teks, verwysing, waarheid: Die relevansie van die verwysingskwessie vir die besinning oor die epistemologiese aard van die dogmatiek. Skrif en kerk 8/2, 154-169.

Eco, U 1983. The name of the rose. London: Picador.

Galloway, F 1990. Breyten Breytenbach as openbare figuur. Pretoria: HAUM. 
Gilfillan, F R 1983. 'Ikoon' - tekens teen hout, in Botha, E \& Pretorius, R (reds), Samehang en sin, 22-29. Kaapstad: Tafelberg.

Hamilton, W 1994. A quest for the post-historical Jesus. New York: Continuum.

Kearney, R 1991. Poetics of imagining: From Husserl to Lyotard. London: Harper.

Kent, J 1989. A renovation of images: Nineteenth-century Protestant 'Lives of Jesus' and Roman Catholic alleged appearances of the blessed virgin Mary, in Jasper D \& Wright, T S (eds), The critical spirit and the will to believe, 37-52. London: Macmillan. (Essays in nineteenth-century literature and religion.)

Kundera, M 1988. The art of the novel. London: Faber.

Kuschel, K J 1986. Theologie und Literatur heute: Themen und Konsequenzen, in Jens W, Küng H \& Kuschel K J (Hrsg), Theologie und Literatur: Zum Stand des Dialogs, 199-222. München: Kindler.

Langenhorst, G 1992. Die literarische Wiederentdeckung Jesu in Romanen der achtziger Jahre. Stimmen der Zeit 210, 751-760.

1995. The rediscovery of Jesus as a literary figure. Literature and Theology 9/1, 85-98.

Oberhaus, D H 1987. 'Tender pioneer': Emily Dickenson's poems on the life of Christ. American Literature 59, 341-358.

Raschke, C 1992. Fire and roses, or the problem of postmodern religious thinking, in Berry, P \& Wernick, A (eds), Shadow of spirit: Postmodernism and religion, 93108. London: Routledge.

Schreiter, R J 1991. Faces of Jesus in Africa. London: SCM.

Slabbert, H le R 1981. Godin en die ikoon: Gedagtes oor religie en kuns in 'Ikoon' van Breytenbach. Tydskrif vir Letterkunde 19/2, 51-55.

Van der Wart, V V 1988. Die woord in die woordkuns: 'n Ondersoek na die gestaltegewing van Christus in die Afrikaanse poësie. Unpublished dissertation, Potchefstroom.

Wessels, A 1986. Images of Jesus: How Jesus is perceived and portrayed in nonEuropean cultures. Michigan: Eerdmans.

Ziolkowski, T 1972. Fictional transfigurations of Jesus. Princeton: Princeton University Press. 